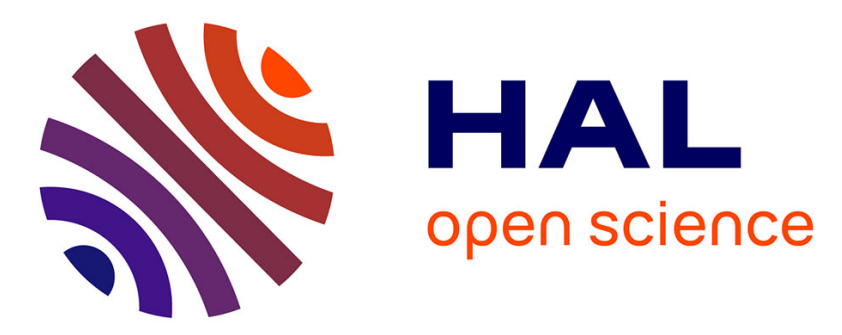

\title{
Mild method of simultaneous methionine grafting and phosphorylation of soybean globulins improves their functional properties
}

\author{
Mahmoud Zaki Sitohy, Yves Popineau, J.M. Chobert, Thomas Haertlé
}

\section{To cite this version:}

Mahmoud Zaki Sitohy, Yves Popineau, J.M. Chobert, Thomas Haertlé. Mild method of simultaneous methionine grafting and phosphorylation of soybean globulins improves their functional properties. Nahrung., 1999, 43 (1), pp.3-8. hal-02694564

\section{HAL Id: hal-02694564 \\ https://hal.inrae.fr/hal-02694564}

Submitted on 1 Jun 2020

HAL is a multi-disciplinary open access archive for the deposit and dissemination of scientific research documents, whether they are published or not. The documents may come from teaching and research institutions in France or abroad, or from public or private research centers.
L'archive ouverte pluridisciplinaire HAL, est destinée au dépôt et à la diffusion de documents scientifiques de niveau recherche, publiés ou non, émanant des établissements d'enseignement et de recherche français ou étrangers, des laboratoires publics ou privés.

$$
\text { Copyright }
$$




\title{
Forschungsbeiträge/Research Papers
}

\section{Mild method of simultaneous methionine grafting and phosphorylation of soybean globulins improves their functional properties}

\author{
M. Sitohy ${ }^{1}$, Y. Popineau*, J.-M. Chobert \\ and T. Haertlé
}

Soybean $7 \mathrm{~S}$ and $11 \mathrm{~S}$ globulins were phosphorylated to different extent as a function of the molar ratios of $\mathrm{POCl}_{3}$ used $(75,150$ and 300 $\mathrm{mol} \mathrm{POCl}_{5} / \mathrm{mol}$ protein) in the presence of equivalent amounts of triethylamine. Simultaneous addition of L-methionine during the phosphorylation yielded methionylated globulins. In some experiments, the basic amino acid arginine was used as the sole base of the reaction, instead of triethylamine, at a ratio of $6 \mathrm{~mol}$ arginine/ $/ \mathrm{mol} \mathrm{POCl}_{3}$. Adding L-methionine in the course of the phosphorylation reaction reduced slightly the extent of protein phosphorylation, with increasing L-methionine content in the phosphorylated globulin up to about $280 \%$ of its original level. The use of L-arginine as the reaction base led to lower phosphorylation yields but could raise simultaneously both L-methionine and L-arginine to about $143 \%$ and $155 \%$ of their original levels, respectively. Isofocusing electrophoresis showed lower isoelectric points of the phosphorylated samples, compared to the starting aliquots. SDS-PAGE did not show major changes in the subunit distribution of the modified soybean globulins. Phosphorylation and "amino acylation" changed the solubility of the modified samples and also other related functional properties e.g. foaming and emulsifying which were remarkably improved, especially for the samples with grafted L-methionine.

\section{Introduction}

Most plant storage proteins are characterized by poor solubility especially around the neutral $\mathrm{pH}$. This is generally due to their high contents of nonpolar amino acids, weak charges, hydrophobic aggregations between the protein subunits and amidation neutralizing the charges of the aspartyl and glutamyl residues [1-3]. Mild chemical phosphorylation of proteins could be a good tool for improving their functional properties such as emulsifying and foaming $[4,5]$.

Functional properties, especially solubility, can be enhanced by chemical phosphorylation [3-11]. Protein solubility is considered an essential feature since other protein functional properties expressed at the interface heavily depend on it. As such, phosphorylation of proteins introduces negative phosphate groups into the protein molecule, bound to lysyl, seryl and threonyl residues and hence increases the net negative charge. As a result, the isoelectric point of the phosphorylated protein is lowered and its solubility at the neutral $\mathrm{pH}$ is improved. Consequently, the enhanced hydrophilicity of the modified protein will decrease the hydrophobically driven aggregations so frequently observed in the plant proteins and improve the general protein solubility. Few studies were performed on the phosphorylation of soybean proteins under conditions involving relatively high amounts of a phosphorylating agent and concentrated inorganic bases [3,12] subjecting the modified proteins to degradation and other uncontrolled changes. The

Institut National de la Recherche Agronomique, LEIMA and *LBTP, Nantes, France.

Correspondence to:

Dr. J. M. Chobert, Institut National de la Recherche Agronomique, LEIMA, B. P. 71627, F-44316 Nantes Cedex 3, France.

${ }^{1}$ Present address: Zagazig University, Faculty of Agriculture, Biochemistry Department, ET-Zagazig, Egypt. proteins involved in these studies were mixtures of whole protein isolates.

The aim of this work was to study the phosphorylation of defined soy protein fractions ( $7 \mathrm{~S}$ and $11 \mathrm{~S}$ soybean globulins) under well-defined mild reaction conditions using equivalent amounts of the phosphorylating agent and the organic base used in order to obtain undegraded phosphorylated, phosphoamidated and phosphodiamidated proteins. Moreover, soybean globulins are originally deficient in L-methionine considered as the main extrinsic amino acid [13]. Its grafting was achieved by the addition of free methionine during the phosphorylation reaction. Grafted amino acids are nutritionally preferable to the addition of free amino acids [14]. L-arginine was also used as the base for the phosphorylation reaction to facilitate the reaction.

\section{Materials and methods}

\subsection{Materials}

Soybean protein globulin fractions were prepared from defated soy flour (Sogip, France) using the method of Thanh and Shibasaki [15]. The method consists in a total solubilisation of albumins and globulins followed by an isoelectric precipitation at $\mathrm{pH} 6.4$ and 4.8 for $11 \mathrm{~S}$ and $7 \mathrm{~S}$ globulins, respectively. After purification, the amount in protein for $11 \mathrm{~S}$ and $7 \mathrm{~S}$ globulins was 89 and $86 \%$, respectively. All other chemicals used were of analytical grade.

\subsection{Protein phosphorylation}

The general procedure of Sitohy et al. [16] was followed for protein phosphorylation. Amounts of phosphorus oxychloride $\left(\mathrm{POCl}_{3}\right)$ equivalent to 75,150 and $300 \mathrm{~mol} / \mathrm{mol}$ protein (based on an average molecular weight of protein subunit of 60,000 ) were dissolved to make $20 \%$ 
solution in carbon tetrachloride. Equivalent amounts of triethylamine ( $6 \mathrm{~mol}$ base $/ \mathrm{mol} \mathrm{POCl}_{3}$ ) were added to a $1 \%$ soybean globulin aqueous solution which was kept cold in an ice-bath. The reaction mixture was stirred for about $5 \mathrm{~min}$ until complete protein solubilisation before the addition dropwise, over $30 \mathrm{~min}$ of the determined amounts of $\mathrm{POCl}_{3}$. The reaction medium was left for $10 \mathrm{~min}$ to achieve complete separation of the aqueous phase which was recovered by decantation, dialyzed for 4 days against several changes of distilled water, and lyophilized. Its phosphorus content was determined according to the method of Bartlett [17] modified by Sitohy et al. [16]. During L-methionine grafting both $7 \mathrm{~S}$ and $11 \mathrm{~S}$ globulins were phosphorylated with a molar ratio of $300 \mathrm{~mol} \mathrm{POCl}_{3} / \mathrm{mol}$ protein while different molar ratios of $\mathrm{L}$ methionine (1, 2 and $4 \mathrm{~mol}$ amino acid/mol $\mathrm{POCl}_{3}$ ) were added dropwise in the course of the phosphorylation reaction. In other experiments, $\mathrm{L}$-arginine was added as a free base at a ratio of $6 \mathrm{~mol}$ amino acid/mol $\mathrm{POCl}_{3}$ in order to replace triethylamine. In this case, $\mathrm{POCl}_{3}$ was used at a ratio of $300 \mathrm{~mol} / \mathrm{mol}$ protein and L-methionine was simultaneously added at a ratio of $2 \mathrm{~mol} / \mathrm{mol} \mathrm{POCl}_{3}$.

\subsection{Protein solubility}

Native and phosphorylated globulins were dispersed in distilled water $(0.1 \% \mathrm{w} / \mathrm{w})$ and the $\mathrm{pH}$ was adjusted from 2 to 7 with concentrated $\mathrm{HCl}$ or $\mathrm{NaOH}$ in order to limit dilution. After 10 min equilibration at room temperature, the dispersion was centrifuged for $15 \mathrm{~min}$ at $2700 \mathrm{~g}$ and $4^{\circ} \mathrm{C}$ and the protein content was determined in the supernatant, as previously described by Chobert et al. [18].

\subsection{SDS-electrophoresis}

SDS-PAGE was performed according to Laemmli [19] on $15 \%$ acrylamide running gel and $3.2 \%$ acrylamide stacking gel, on a Mini Protean II (Bio-Rad) apparatus. Proteins were stained with $0.2 \%$ Coomassie brilliant blue R250.

\subsection{Isofocusing electrophoresis}

Electrofocusing was performed in the $\mathrm{pH}$ range $3-7$ on ready-touse isoelectric focusing gels (FMC, Rockland, USA). A marker kit of $\mathrm{pI}$ in the range 3.50-7.35 was used for calibration (Pharmacia, Sweden).

\subsection{Amino acid analysis}

Acid hydrolysis of protein was realized under vacuum in the presence of $6 \mathrm{~N} \mathrm{HCl}$ for $24 \mathrm{~h}$, at $110^{\circ} \mathrm{C}$ in a Pico-Tag station (Waters). Amino acids were derivatized with phenylisothiocyanate (PITC) according to the method described by Bidlingmeyer et al. [20] and quantified by reversed-phase HPLC on a Pico-Tag $\mathrm{C}_{18}$ column (3.98 mm i. d. $\times 15 \mathrm{~cm}$, Waters).

\subsection{Emulsifying properties}

Emulsions were realized at $\mathrm{pH} 7$ using $0.1 \%$ protein solution and corn oil. Emulsifying activity index (EAI) was determined according to the procedure outlined by Chobert et al. [21]. Emulsion stability kinetics were determined according to the methods described by Dagorn-Scaviner et al. [22] and Loisel and Popineau [23].

\subsection{Foaming properties}

The foaming propertics of native and phosphorylated soybean globulin solutions $(0.4 \mathrm{mg} / \mathrm{ml})$ prepared in $0.1 \mathrm{M}$ phosphate buffer, $\mathrm{pH}$ 7.0 , were measured with a recently described apparatus $[24,25]$.

\section{Results and discussion}

\subsection{Extent of phosphorylation}

Both soybean globulin fractions (7S and 11S) were phosphorylated to considerable extents when using relatively low
Table 1. Extent of soybean globulin phosphorylation with different molar ratios of phosphorus oxychloride.

\begin{tabular}{lcccc}
\hline Sample & $\begin{array}{c}\text { Molar ratio } \\
\text { [mol POCl } 1_{3} / \\
\text { mol protein] }\end{array}$ & $\begin{array}{c}\text { Total } \\
\mathrm{P}[\%]\end{array}$ & $\begin{array}{c}\text { Bound } \\
\mathrm{P}[\%]\end{array}$ & $\begin{array}{c}\text { Extent of phosphor- } \\
\text { ylation [mol P/mol } \\
\text { protein] }\end{array}$ \\
\hline 7S globulin & 0 & 0.68 & 0 & 0 \\
& 75 & 1.35 & 0.67 & 9 \\
& 150 & 1.65 & 0.97 & 13 \\
11S globulin & 300 & 1.76 & 1.08 & 18 \\
& 0 & 0.31 & 0 & 0 \\
& 75 & 1.34 & 1.03 & 10 \\
& 150 & 1.52 & 1.21 & 13 \\
& 300 & 1.65 & 1.34 & 21 \\
\hline
\end{tabular}

molar ratios of $\mathrm{POCl}_{3}$ in the presence of equivalent amounts of triethylamine (Table 1). The extent of phosphorylation was proportional to the molar ratio of $\mathrm{POCl}_{3}$, and comparable to that obtained by Hirotsuka et al. [12] for soybean isolate phosphorylated with $\mathrm{POCl}_{3}$ in the presence of an excess of sodium hydroxide. The use of triethylamine at an amount exactly equivalent to the amount used for $\mathrm{POCl}_{3}$ was intended to keep the protein molecule in an undegraded form during and after the phosphorylation reaction.

\subsection{Methionine grafting and extent of phosphorylation}

Methionine was grafted on soybean globulin molecules with considerable yields during the phosphorylation. The quantity of methionine was increased to $281 \%$ and $215 \%$ of its original amount in $7 \mathrm{~S}$ and $11 \mathrm{~S}$ globulins, respectively. The grafted methionine amounted to 2,4 and 8 mol methionine/mol soybean globulin ( $7 \mathrm{~S}$ and $11 \mathrm{~S}$ ) when the amino acid was added to the phosphorylation reaction medium at levels of 1,2 and 4 $\mathrm{mol} / \mathrm{mol} \mathrm{POCl}_{3}$, respectively. Increasing the amount of added L-methionine increased gradually its grafting while reducing slightly the phosphorylation yield (Table 2). This could be caused by the competition between the $\mathrm{NH}_{2}$ group of free methionine and the protein molecules for the phosphorylating agent. L-methionine is linked to the protein molecule through two phosphoamide bonds connecting the protein molecule and L-methionine.

When using the phosphorylating agent at $300 \mathrm{~mol} \mathrm{POCl}_{3} /$ mol protein, triethylamine was replaced by free L-arginine at $6 \mathrm{~mol} / \mathrm{mol} \mathrm{POCl}_{3}$ as the sole source of base for the phosphorylation reaction. L-methionine was added at a ratio of $2 \mathrm{~mol} /$ mol $\mathrm{POCl}_{3}$. It resulted in lower phosphorylation yield (14 and $15 \mathrm{~mol} \mathrm{P} / \mathrm{mol}$ protein for $7 \mathrm{~S}$ and $11 \mathrm{~S}$ globulins, respectively). The yields of grafted methionine increased only by about 43 and $31 \%$ over its original content in $7 \mathrm{~S}$ and $11 \mathrm{~S}$ globulins, respectively. This corresponds to $2 \mathrm{~mol}$ methionine grafted to one mol globulin. Simultaneously, L-arginine content was increased by about $55 \%$ for $7 \mathrm{~S}$ and $11 \mathrm{~S}$ globulins, leading to the grafting of 23 arginine on one molecule of soybean globulin. Theoretically, the number of phosphate groups bound to one $7 \mathrm{~S}$ or $11 \mathrm{~S}$ globulin (14 and 15 moles $\mathrm{P} / \mathrm{mol}$ globulin, respectively) is quite sufficient to bind the amino acids. Lower yield of grafted L-methionine seems to be due to the lower phosphorylation, confirming the role of remaining activated phosphate groups in secondary grafting of the amino acids on soybean globulins. Moreover, the presence of both arginine 
Table 2. Extent of phosphorylation and methionine grafting on soybean $7 \mathrm{~S}$ and $11 \mathrm{~S}$ globulins.

\begin{tabular}{|c|c|c|c|c|c|c|}
\hline Sample & $\begin{array}{l}\text { Molar ratio } \\
{\left[\mathrm{mol} \mathrm{POCl}_{3} /\right.} \\
\text { mol protein] }\end{array}$ & $\begin{array}{c}\text { Molar ratio } \\
\text { [mol methionine/ } \\
\text { mol protein] }\end{array}$ & $\begin{array}{c}\text { Bound P } \\
\text { [mol P/mol protein] }\end{array}$ & Total Met [\%] & {$[\%]$} & $\begin{array}{l}\text { Ind Met } \\
\text { [mol methionine/ } \\
\text { mol protein] }\end{array}$ \\
\hline $7 \mathrm{~S}$ globulin & $\begin{array}{r}0 \\
300 \\
300 \\
300\end{array}$ & $\begin{array}{l}0 \\
1 \\
2 \\
4\end{array}$ & $\begin{array}{r}0 \\
20 \\
18 \\
15\end{array}$ & $\begin{array}{l}1 \\
1.37 \\
2.01 \\
2.81\end{array}$ & $\begin{array}{l}0 \\
0.37 \\
1.01 \\
1.81\end{array}$ & $\begin{array}{l}0 \\
2 \\
5 \\
8\end{array}$ \\
\hline 11S globulin & $\begin{array}{r}0 \\
300 \\
300 \\
300\end{array}$ & $\begin{array}{l}0 \\
1 \\
2 \\
4\end{array}$ & $\begin{array}{r}0 \\
21 \\
18 \\
16\end{array}$ & $\begin{array}{l}1.48 \\
2.01 \\
2.41 \\
3.21\end{array}$ & $\begin{array}{l}0 \\
0.53 \\
0.93 \\
1.73\end{array}$ & $\begin{array}{l}0 \\
2 \\
4 \\
8\end{array}$ \\
\hline
\end{tabular}

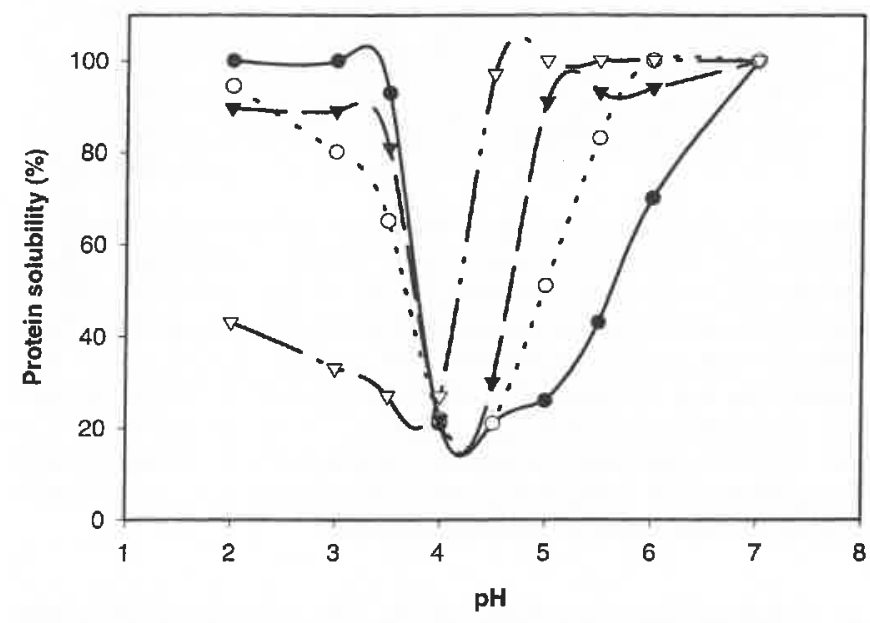

Figure 1. pH-solubility profiles of native $(\bullet)$ and phosphorylated $7 \mathrm{~S}$ soybean globulins. (o) $9 ;(\nabla) 13$ and $(\nabla) 18 \mathrm{~mol} \mathrm{P} / \mathrm{mol}$ protein.

and methionine in the reaction medium leads to a competition between two amino acids to react with the activated phosphate group. This is strengthened by greater reactivity of arginine because of its higher basicity and its presence in a higher concentration in the reaction medium.

\subsection{Protein solubility}

The solubility of soybean globulins was highly improved by phosphorylation especially in the pH-ranges 4.5-7 and 5-7 for $7 \mathrm{~S}$ and $11 \mathrm{~S}$ globulins, respectively (Figures 1 and 2). This increase of protein solubility is not only due to the shift of the isoelectric points towards acidic side but also to the enhanced hydrophilicity resulting from the addition of negatively charged phosphate groups to the protein. However, at lower pHs (2.0-3.5) solubility of the phosphorylated samples was greatly reduced especially for the highest substitution yields. This may result from the protonation of the free phosphate groups which are responsible for the protein solubility.

\subsection{Electrophoretic patterns of phosphorylated globulins}

SDS-PAGE patterns of phosphorylated soybean 7S and 11S globulins are not different from the native corresponding samples (Fig. 3) indicating that the mild reaction conditions used did not degrade notably any of the modified proteins.

The isofocusing electrophoresis of the modified samples (Fig. 4) shows a decrease of the pI values of the phosphoryl-

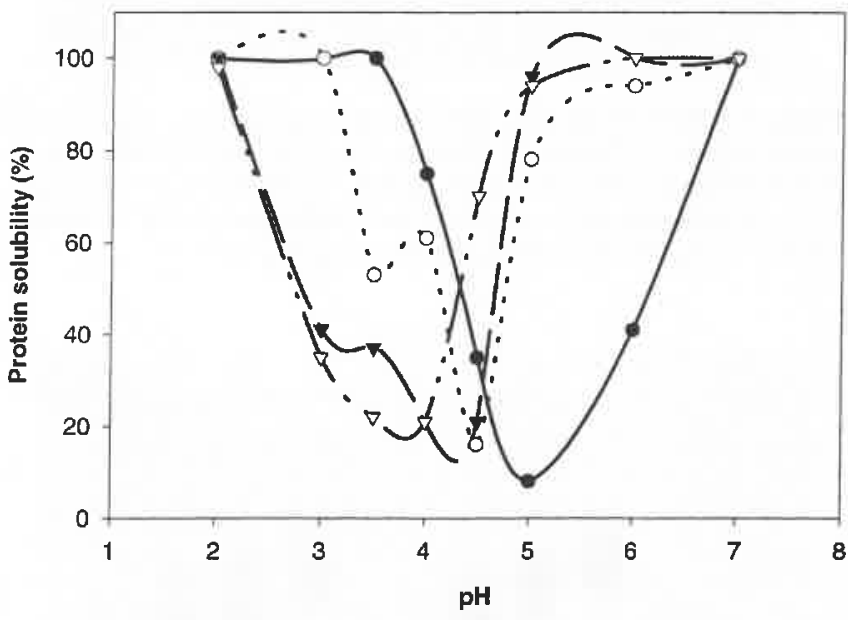

Figure 2. pH-solubility profiles of native (๑) and phosphorylated 11 S soybean globulins. (o) $10 ;(\nabla) 13$ and $(\nabla) 21 \mathrm{~mol} \mathrm{P} / \mathrm{mol}$ protein.

ated samples, compared to the starting material. The magnitude of the modification of the $\mathrm{pI}$ values is directly proportional to the extent of phosphorylation. This shows clearly that the introduction of a negative phosphate group into the protein molecule can directly change the net negative charge and also the isoelectric point of the modified protein. The systematic decrease of the isoelectric point according to the phosphorylation yield confirms the covalent character of the modification of the protein molecule and can be also used as an indicator of the extent of phosphorylation.

The isoelectrofocusing of the phosphorylated soybean globulins samples with grafted L-methionine (Fig. 5) show also the decrease of pI, according to the extent of phosphorylation. The relatively low amount of attached L-methionine molecules (2-8 molecules/protein molecule) compared with the bigger quantity of attached phosphate groups (15-21 mol/mol protein) did not significantly affect the negative charges of the bound phosphate groups. The same trend was observed in case of both $7 \mathrm{~S}$ and $11 \mathrm{~S}$ globulins indicating that the change of the electrophoretic patterns is a function of the extent of phosphorylation only. The use of L-arginine as the sole base of the reaction did not change the trend of the electrophoretic pattern except that the magnitude of the reduction of the $\mathrm{pI}$ value was lower than for the other phosphorylated samples. This could be interpreted as a consequence of a relatively lower extent of phosphorylation (Fig. 5 and Tab. 2). The grafted arginyl residues neutralized the negative charges of the protein boundphosphate groups on which they were bound. This is illustrated 


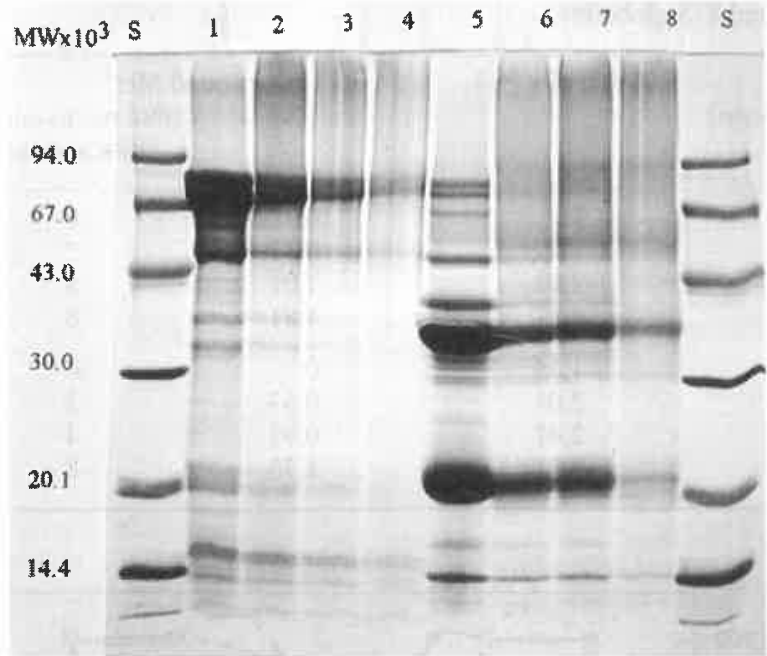

Figure 3. SDS-PAGE of 7S and 11S soybean globulins. S: Molecular weight marker; 1: Native 7S globulin; 2-4: 7S globulins phosphorylated at different extent $(9,13$ and $18 \mathrm{~mol} \mathrm{P} / \mathrm{mol}$ protein, respectively); 5: Native 11S globulin; 6-8: 11S globulins phosphorylated at different extent (10, 13 and $21 \mathrm{~mol} \mathrm{P/mol} \mathrm{protein,} \mathrm{respectively).}$

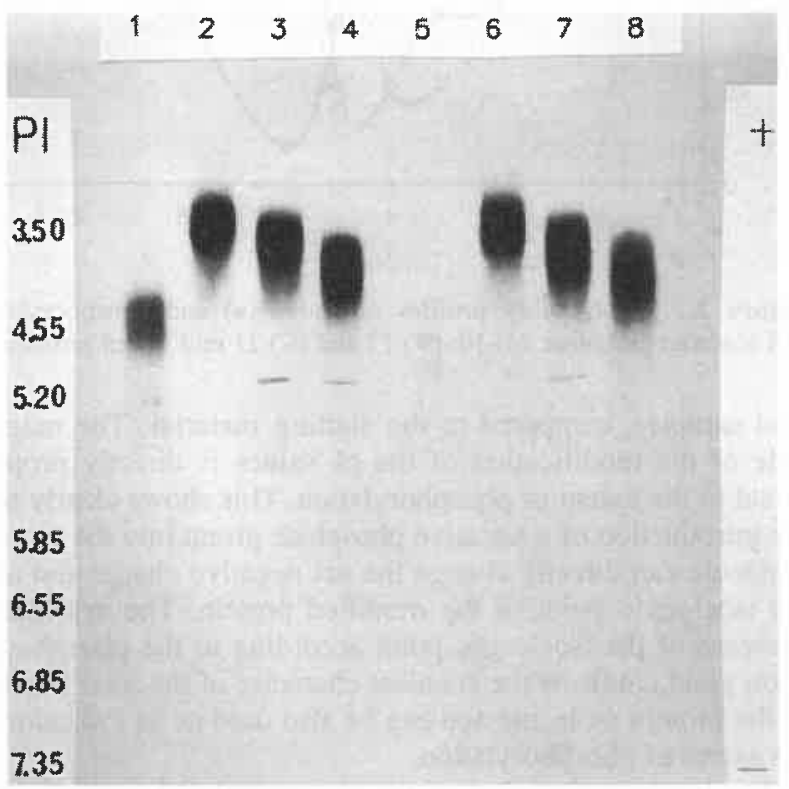

Figure 4. Isoelectrofocusing of $7 \mathrm{~S}$ and $11 \mathrm{~S}$ globulins. 1: Native $7 \mathrm{~S}$ globulin; 2-4: 7S globulins phosphorylated at different extents $(18,13$ and $9 \mathrm{~mol} \mathrm{P} / \mathrm{mol}$ protein, respectively); 5: Native $11 \mathrm{~S}$ globulin; 6-8: $11 \mathrm{~S}$ globulins phosphorylated at different extents $(21,13$ and $10 \mathrm{~mol}$ $\mathrm{P} / \mathrm{mol}$ protein, respectively).

by the slight reduction in the isoelectric point of the argininegrafted samples compared with the other phosphorylated samples (Fig. 5).

\subsection{Foaming properties}

The foaming properties of phosphorylated soybean $7 \mathrm{~S}$ and $11 \mathrm{~S}$ globulins are presented in Table 3. Native $7 \mathrm{~S}$ globulin displays very low foaming capacity since its maximal hydration, as measured by the liquid volume, is $1.6 \mathrm{ml}$ in $50 \mathrm{ml}$ foam. The foaming capacity of the native $11 \mathrm{~S}$ globulin is even worse

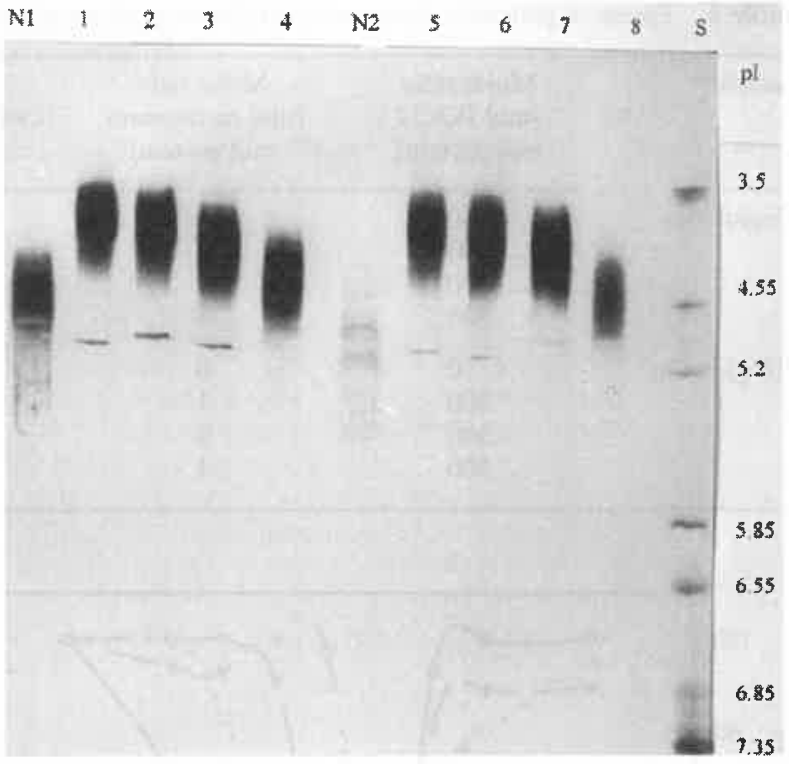

Figure 5. Isoelectrofocusing of $7 \mathrm{~S}$ and $11 \mathrm{~S}$ globulins. N1: Native $7 \mathrm{~S}$ globulin; N2: Native 11S globulin; S: pI marker; 1-3: Phosphorylated $7 \mathrm{~S}$ globulins with grafted methionine $(20,18$ and $15 \mathrm{~mol} \mathrm{P}$, and 2,5 and $8 \mathrm{~mol}$ methionine/mol protein, respectively); 4: Phosphorylated $7 \mathrm{~S}$ globulin with grafted methionine and arginine (14 mol P, $2 \mathrm{~mol}$ methionine and $23 \mathrm{~mol}$ arginine/mol protein); 5-7: Phosphorylated 11 globulins with grafted methionine $(21,19$ and $16 \mathrm{~mol} \mathrm{P}$, and 2,4 and $8 \mathrm{~mol}$ methionine/mol protein, respectively); 8: Phosphorylated $11 \mathrm{~S}$ globulin with grafted methionine and arginine (15 mol P, 2 mol methionine and $23 \mathrm{~mol}$ arginine $/ \mathrm{mol}$ protein).

as it did not form any foam at all. The stability of the foam obtained with native $7 \mathrm{~S}$ globulin was very poor as demonstrated by the half-life time $(128 \mathrm{sec})$. These poor foaming properties may be due to the low protein solubility of native soybean globulins around the neutral $\mathrm{pH}$ range what impedes the process of foam hydration.

Phosphorylation of $7 \mathrm{~S}$ globulin highly enhanced its foaming capacity by increasing its foam hydration nearly four times the value obtained for the native globulin, and by doubling its foam stability as deduced from its half-life time. This improvement of the foaming properties may be due to an enhanced solubility of the phosphorylated soybean $7 \mathrm{~S}$ globulin and more precisely to the presence of bound phosphate groups on the protein molecules enhancing protein hydrophilicity and consequently playing a major role in the foam hydration. Foam collapse is delayed because of the coulombic repulsions between the strong negative charges of the free phosphate groups attached to the modified globulin molecules. This agrees with the previous observation that low extent of phosphorylation is beneficial for the foaming properties of casein [26]. The foaming capacity and stability values attained by phosphorylated $11 S$ globulin samples were comparable with those obtained with phosphorylated $7 \mathrm{~S}$ globulin since the phosphorylation yields were nearly identical in both cases.

Phosphorylated 7S and 11S globulins containing grafted Lmethionine achieved foaming capacity levels higher from those obtained without amino acid grafting (Table 4). The stability of phosphorylated samples with grafted methionine was nearly twice bigger from that obtained in case of samples phosphorylated only. This additive improvement of foaming properties is due merely to additional modification induced by the secondary grafting of amino acid. The grafted methionine 
Table 3. Foaming properties of phosphorylated soybean globulins.

\begin{tabular}{|c|c|c|c|c|c|}
\hline Protein sample & $\begin{array}{c}1 \\
\mathrm{TF}[\mathrm{s}]\end{array}$ & $\stackrel{2}{\mathrm{FV} \max [\mathrm{ml}]}$ & $\begin{array}{c}3 \\
\mathrm{LV} \max [\mathrm{ml}]\end{array}$ & $\begin{array}{c}4 \\
\text { LV } 20 \min [\mathrm{ml}]\end{array}$ & $\begin{array}{c}5 \\
\text { HL }[s]\end{array}$ \\
\hline Native $7 \mathrm{~S}$ globulin & 196 & 50 & $1.6 \pm 0.02$ & $0.4 \pm 0.02$ & $128 \pm 4$ \\
\hline $\begin{array}{l}\text { Phospho-7S globulin } \\
9 \mathrm{~mol} \mathrm{P} / \mathrm{mol} \text { protein } \\
13 \mathrm{~mol} \mathrm{P} / \mathrm{mol} \text { protein } \\
18 \mathrm{~mol} \mathrm{P} / \mathrm{mol} \text { protein }\end{array}$ & $\begin{array}{l}189 \\
189 \\
189\end{array}$ & $\begin{array}{l}50 \\
50 \\
50\end{array}$ & $\begin{array}{l}6.4 \pm 0.06 \\
6.1 \pm 0.06 \\
6.7 \pm 0.06\end{array}$ & $\begin{array}{l}1.6 \pm 0.05 \\
1.3 \pm 0.05 \\
1.3 \pm 0.05\end{array}$ & $\begin{array}{l}285 \pm 11 \\
268 \pm 10 \\
275 \pm 10\end{array}$ \\
\hline Native $11 \mathrm{~S}$ globulin & 0 & 0 & 0 & 0 & 0 \\
\hline $\begin{array}{l}\text { Phospho-11S globulin } \\
10 \mathrm{~mol} \mathrm{P} / \mathrm{mol} \text { protein } \\
13 \mathrm{~mol} \mathrm{P} / \mathrm{mol} \text { protein } \\
21 \mathrm{~mol} \mathrm{P} / \mathrm{mol} \text { protein }\end{array}$ & $\begin{array}{l}192 \\
191 \\
188\end{array}$ & $\begin{array}{l}50 \\
50 \\
50\end{array}$ & $\begin{array}{l}6.3 \pm 0.06 \\
6.3 \pm 0.06 \\
5.6 \pm 0.06\end{array}$ & $\begin{array}{l}2.1 \pm 0.08 \\
1.6 \pm 0.05 \\
1.2 \pm 0.04\end{array}$ & $\begin{array}{l}373 \pm 11 \\
299 \pm 10 \\
218 \pm 9\end{array}$ \\
\hline
\end{tabular}

1: Time of foaming; 2: Maximum foam volume; 3: Maximum liquid volume in foam; 4: Liquid volume after 20 min; 5 : Half-life of foam.

Table 4. Foaming properties of phosphorylated and methionine-grafted soybean globulins.

\begin{tabular}{|c|c|c|c|c|c|}
\hline Protein & $\begin{array}{c}1 \\
\mathrm{TF}[\mathrm{s}]\end{array}$ & $\stackrel{2}{\text { FV max }[\mathrm{ml}]}$ & $\stackrel{3}{\mathrm{LV} \max [\mathrm{ml}]}$ & $\begin{array}{l}4 \\
\mathrm{LV} 20 \mathrm{~min}[\mathrm{ml}]\end{array}$ & $\stackrel{5}{\mathrm{HL}[\mathrm{s}]}$ \\
\hline Native $7 \mathrm{~S}$ globulin & 196 & 50 & $1.6 \pm 0.02$ & $0.4 \pm 0.02$ & $128 \pm 4$ \\
\hline \multicolumn{6}{|l|}{ Phospho-7S globulin } \\
\hline $\begin{array}{l}20 \mathrm{~mol} \mathrm{P} / \mathrm{mol} \text { protein }+2 \mathrm{~mol} \mathrm{Met} / \mathrm{mol} \\
\text { protein }\end{array}$ & 189 & 50 & $7.2 \pm 0.07$ & $2.0 \pm 0.08$ & $550 \pm 17$ \\
\hline $\begin{array}{l}18 \mathrm{~mol} \mathrm{P} / \mathrm{mol} \text { protein }+5 \mathrm{~mol} \mathrm{Met} / \mathrm{mol} \\
\text { protein }\end{array}$ & 189 & 50 & $7.2 \pm 0.07$ & $2.5 \pm 0.09$ & $576 \pm 18$ \\
\hline $\begin{array}{l}15 \mathrm{~mol} \mathrm{P} / \mathrm{mol} \text { protein }+8 \mathrm{~mol} \mathrm{Met} / \mathrm{mol} \\
\text { protein }\end{array}$ & 189 & 50 & $7.5 \pm 0.07$ & $2.5 \pm 0.09$ & $580 \pm 18$ \\
\hline $\begin{array}{l}12 \mathrm{~mol} \mathrm{P} / \mathrm{mol} \text { protein }+2 \mathrm{~mol} \mathrm{Met} / \mathrm{mol} \\
\text { protein }+23 \mathrm{~mol} A \mathrm{rg} / \mathrm{mol} \text { protein }\end{array}$ & 189 & 50 & $8.1 \pm 0.08$ & $2.3 \pm 0.08$ & $660 \pm 21$ \\
\hline Native 11S globulin & 0 & 0 & 0 & 0 & 0 \\
\hline \multicolumn{6}{|l|}{ Phospho-11S globulin } \\
\hline $\begin{array}{l}21 \mathrm{~mol} \mathrm{P} / \mathrm{mol} \text { protein }+2 \mathrm{~mol} \mathrm{Met} / \mathrm{mol} \\
\text { protein }\end{array}$ & 192 & 50 & $7.2 \pm 0.07$ & $1.8 \pm 0.06$ & $540 \pm 17$ \\
\hline $\begin{array}{l}18 \mathrm{~mol} \mathrm{P} / \mathrm{mol} \text { protein }+5 \mathrm{~mol} \mathrm{Met} / \mathrm{mol} \\
\text { protein }\end{array}$ & 191 & 50 & $7.1 \pm 0.07$ & $1.6 \pm 0.06$ & $540 \pm 17$ \\
\hline $\begin{array}{l}16 \mathrm{~mol} \mathrm{P} / \mathrm{mol} \text { protein }+8 \mathrm{~mol} \mathrm{Met} / \mathrm{mol} \\
\text { protein }\end{array}$ & 188 & 50 & $6.9 \pm 0.07$ & $1.7 \pm 0.06$ & $540 \pm 17$ \\
\hline $\begin{array}{l}18 \mathrm{~mol} \mathrm{P} / \mathrm{mol} \text { protein }+2 \mathrm{~mol} \mathrm{Met} / \mathrm{mol} \\
\text { protein }+23 \mathrm{~mol} \mathrm{Arg} / \mathrm{mol} \text { protein }\end{array}$ & 190 & 50 & $7.9 \pm 0.08$ & $2.3 \pm 0.08$ & $650 \pm 20$ \\
\hline
\end{tabular}

1: Time of foaming; 2: Maximum foam volume; 3: Maximum liquid volume in foam; 4: Liquid volume after 20 min; 5: Half-life of foam.

moieties diminish the strong negative charges of the phosphate groups on the modified protein molecule.

The soybean globulin samples phosphorylated in the presence of L-arginine and L-methionine - and containing both grafted amino acids - exhibited the highest foaming capacity and stability among all the phosphorylated samples. This again shows that amino acids grafted on the phosphate groups of the modified samples improved further their foaming properties by neutralizing the excessive negative charge of the phosphate groups while maintaining partial charges still big. enough to induce the hydration of the protein foam. It can also be concluded that the grafted arginine had more powerful modifying effect than methionine because of its chemical character. As a dibasic amino acid, arginine binds to the phosphate group by primary amino group while still having a free guanidine and a free carboxyl group. Consequently, the final result of grafting is the replacement of one negative charge on the free phosphate groups by a grafted amino acid with a zero net charge, but displaying a great hydrophilic capacity. The influence of grafted arginine on the net negative charge can be seen on the isofocusing patterns (Fig. 5). These products may be quite interesting from a nutritional point of view since they are prepared without the use of the organic base triethylamine unacceptable for alimentary purposes and which otherwise should be removed from the final products.

\subsection{Emulsifying properties}

The phosphoamidated with methionine $7 \mathrm{~S}$ and $11 \mathrm{~S}$ globulins showed improved emulsifying activity and stability when compared with the native globulins (Fig. 5 and 6). The soybean globulins phosphorylated in the absence of methionine exhibited similar emulsifying behavior (data not shown). Hence, this improvement in emulsifying properties is due mainly to the presence on the globulin of the phosphates conferring bigger hydrophilicity to globulin molecule and counter- 


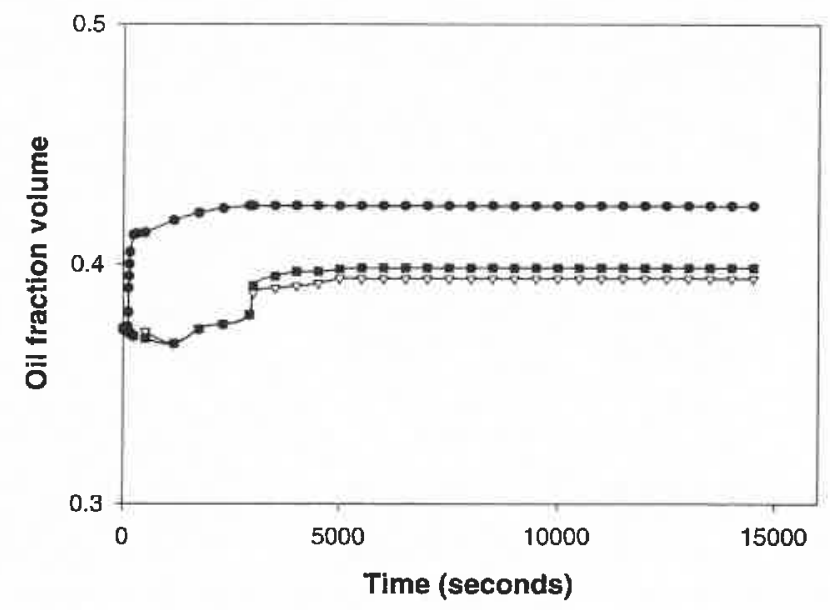

Figure 6. Emulsion stability curves for 7S globulins. ( $\bullet$ Native; Phosphorylated and methionine grafted [(*): $22 \mathrm{~mol} \mathrm{P}$ and $2 \mathrm{~mol}$ methionine/mol protein; $(\nabla) 15 \mathrm{~mol} \mathrm{P}$ and $8 \mathrm{~mol}$ methionine/mol protein].

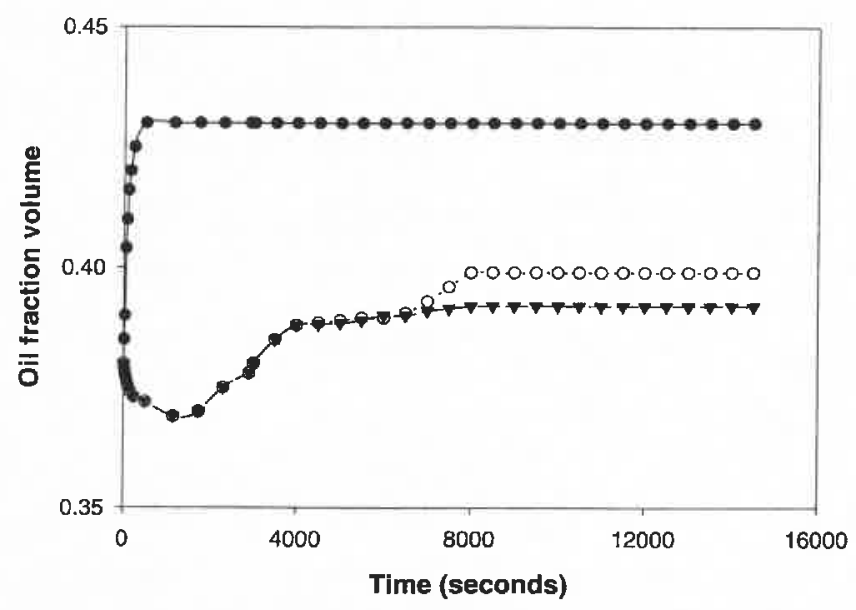

Figure 7. Emulsion stability curves for $11 \mathrm{~S}$ globulins. (•) Native; Phosphorylated and methionine grafted [(o): $21 \mathrm{~mol} \mathrm{P}$ and $2 \mathrm{~mol}$ methionine/mol protein; ( $)$ : $16 \mathrm{~mol} \mathrm{P}$ and $8 \mathrm{~mol}$ methionine/mol protein].

balancing its original hydrophobicity. Methionine grafted on the globulin phosphate groups did not change their activity in promoting formation of emulsion and increasing its stability. Generally, the improvement of the emulsifying properties of the phosphorylated proteins agrees well with the results of Sung et al. [3], Hirotsuka et al. [12] and Huang and Kinsella [6]. These authors attributed this improvement to the increase of number of negative charges on the phosphorylated proteins which tends to induce strong electrostatic repulsions between the negatively charged emulsion surfaces reducing thus the coalescence of the emulsions.

\section{Conclusion}

The extent of soybean $7 \mathrm{~S}$ and $11 \mathrm{~S}$ globulins phosphorylation can be controlled by varying the reaction conditions, also by the simultaneous addition of L-methionine which can divert the reaction towards methionylated globulins. Surprisingly, the electrophoretic patterns of the phosphorylated proteins did not show major changes in the subunit distribution of the modified soybean globulins. The functional properties of the modified proteins strongly depend on the extent of phosphorylation and amino acylation as for example the foaming and emulsifying properties which get improved remarkably, especially in case of the samples with grafted L-methionine. As can be seen, this simple approach using nutritionally acceptable reagents can constitute an efficient way to modify the functional properties of these classes of proteins. Since it is of a general character, it is clear that the application of this simple method can be extended to other proteins.

\section{References}

[1] Puri, B. R., U. Gupta and N. Bala, Indian J. Chem. 14 (1976) 243-247.

[2] Wasik, R. J., M. Daoust and C. Martin, Cereal Chem. 56 (1979) 90-94.

[3] Sung, H. Y., H. J. Chen, T. Liu and J. C. Su, J. Food Sci. 48 (1983) $716-721$.

[4] Huang, Y. T., and J. E. Kinsella, J. Agric. Food Chem. 34 (1986) 670.

[5] Matheis, G., Food Chem. 39 (1991) 13-26.

[6] Huang, Y. T., and J. E. Kinsella, Biotechnol. Bioeng. 28 (1986) 1690.

[7] Huang, Y. T., and J. E. Kinsella, J. Food Sci. 52 (1987) 16841688.

[8] Matheis, G., and J. R. Whitaker, J. Food Biochem. 8 (1984) $137-162$.

[9] Matheis, G., and J. R. Whitaker, J. Food Chem. 32 (1984) 690705.

[10] Matheis, G., H. M. Penner, R. E. Feeney and J. R. Whitaker, J. Agric. Food Chem. 31 (1983) 379-387.

[11] Mohammed, A., D. K. Mecham and H. S. Olcott, Agric. Food Chem. 2 (1954) 136-137.

[12] Hirotsuka, M., H. Taniguchi, H. Narita and M. Kito, Agric. Biol. Chem. 48 (1984) 93-100.

[13] Wolf, W. J., Food Technol. 26 (1972) 44.

[14] Voutsinas, L. P., and S. Nakai, J. Food Sci. 44 (1979) 12051211.

[15] Thanh, V. H., and K. Shibasaki, J. Agric. Food Chem. 24 (1976) $1117-1121$.

[16] Sitohy, M., J. M. Chobert and T. Haertlé, Milchwissenschaft 49 (1994) 610-615.

[17] Bartlett, G. R., J. Biol. Chem. 234 (1959) 466-468.

[18] Chobert, J. M., A. Towati, C. Bertrand-Harb, M. Dalgalarrondo, M. G. Nicolas and T. Haertlé, J. Dairy Res. 58 (1991) 285-298.

[19] Laemmli, U. K., Nature 227 (1970) 680-685.

[20] Bidlingmeyer, B. A., S. A. Cohen and T. L. Tarvin, J. Chromatogr. 336 (1984) 93-104.

[21] Chobert, J. M., C. Bertrand-Harb, M. G. Nicolas, H. F. Gaertner and A. J. Puigserver, J. Agric. Food Chem. 35 (1987) 638-644.

[22] Dagorn-Scaviner, C., J. Guéguen and J. Lefèbvre, J. Food Sci. 52 (1987) 335-341.

[23] Loisel, W., and Y. Popineau, Procédé et matériel de caractérisation de la stabilité d'une émulsion. Demande de brevet français 1993.

[24] Guillerme, C., W. Loisel, D. Bertrand and Y. Popineau, J. Texture Studies 24 (1993) 287-302.

[25] Loisel, W., J. Guéguen and Y. Popineau, in: Food proteins: structure and functionality. Ed. by $K . D$. Schwenke, and R. Mothes, pp. 320-323, VCH, Weinheim 1993.

[26] Sitohy, M., J. M. Chobert and T. Haertlé, J. Food Biochem. 19 (1995) $97-108$.

Received: 19 January 1998.

Accepted: 24 April 1998. 